九州大学学術情報リポジトリ

Kyushu University Institutional Repository

\title{
Utilization of Groundnut Shell as Reinforcement in Development of Aluminum Based Composite to Reduce Environment Pollution: a review
}

Dwivedi, Prakash, Shashi

Department of Mechanical Engineering, G. L. Bajaj Institute of Technology and Management

Maurya, Manish

Department of Mechanical Engineering, Accurate Institute of Management and Technology

Maurya, Kumar, Nagendra

Department of Mechanical Engineering, G.L. Bajaj Institute of Technology and Management

Srivastava, Kumar, Ashish

Department of Mechanical Engineering, G.L. Bajaj Institute of Technology and Management

他

https://doi.org/10.5109/2740937

出版情報 : Evergreen. 7 (1)，pp.15-25，2020-03. 九州大学グリーンテクノロジー研究教育センター バージョン：

権利関係 : 


\title{
Utilization of Groundnut Shell as Reinforcement in Development of Aluminum Based Composite to Reduce Environment Pollution: a review
}

\author{
Shashi Prakash Dwivedi ${ }^{1}$, Manish Maurya ${ }^{2}$, Nagendra Kumar Maurya ${ }^{1 *}$, Ashish \\ Kumar Srivastava ${ }^{1}$, Satpal Sharma ${ }^{3}$, Ambuj Saxena ${ }^{1}$ \\ ${ }^{1}$ Department of Mechanical Engineering, G.L. Bajaj Institute of Technology and Management, Greater \\ Noida -201308, India \\ ${ }^{2}$ Department of Mechanical Engineering, Accurate Institute of Management and Technology, Greater Noida - \\ 201308, India \\ ${ }^{3}$ Department of Mechanical Engineering, Gautam Budha University, Gautam Budha Nagar -201310, India
}

*Author to whom correspondence should be addressed:

E-mail:nagendramnnit@gmail.com

(Received November 16, 2019; Revised January 28, 2020; accepted March 2, 2020).

\begin{abstract}
There are various types of reinforcements used in the development of aluminium based metal matrix composites. It was observed that by the use of ceramic particles, mechanical characteristics such as hardness and tensile strength were enhanced. However, density and cost was also increased. Groundnut shell is waste product that produces lots of soil pollution. By utilizing ground nut shell ash as reinforcement material with aluminium, mechanical properties can be improved. Further, density and cost of composite can be reduced. The aim of this review article is to study the influence of various types of reinforcements in the fabrication of composites with enhanced mechanical properties.
\end{abstract}

Keywords: Waste products, groundnut shell ash, tensile strength, hardness, density.

\section{Introduction}

As the name tells us that, in metal matrix composites, the matrix phase should be in the form of metal like aluminium, magnesium, titanium. Metals are mainly reinforced to increase or decrease the properties according to the requirement of needed design ${ }^{1}$. Metal matrix composites provide following advantages- it includes modulus and higher specific strength by reinforcing low density metals like aluminium and titanium; Lower coefficients of thermal expansion by reinforcing with fibers of low coefficient of thermal expansions such as graphite; and maintaining properties such as strength at high temperature ${ }^{2}$. Metal matrix composites provide several advantages as compared to polymer matrix composites that include higher service temperature, higher elastic properties, better wear, fatigue and flaw resistance and higher electric and thermal conductivity ${ }^{3}$. In comparison to polymer matrix composite, metal matrix composites have some drawbacks such as higher processing temperature and higher densities ${ }^{4)}$.

When two or more than two reinforcements are added to the matrix then the resulting composite is called hybrid composite. Addition of reinforcement materials had increased the mechanical characteristics like hardness and tensile strength of composite. The reinforcement for a matrix alloy is selected based on the property requirement for the composite, wettability of the reinforcement and the matrix compatibility Hybrid metal matrix composites imparts the expected properties by bringing the combined advantages of both matrix and reinforcement into full play, which gives us a rather high degree of freedom in material design ${ }^{5}$. Various techniques present to present composites are shown in Fig 1. In this review article, focus is presented on the composites prepared through stir casting technique.

\section{1 Green Metal Matrix Composites}

Green manufacturing is a business technique that focuses on profitability through environmentally friendly operating processes. Groundnut shell is an aviculture by product that has been listed worldwide as one of the worst environmental problems ${ }^{6}$. The effective utilization of groundnut shell in development of aluminium based composite is strongly encouraged in our society for environmental and economic reasons ${ }^{7)}$. 


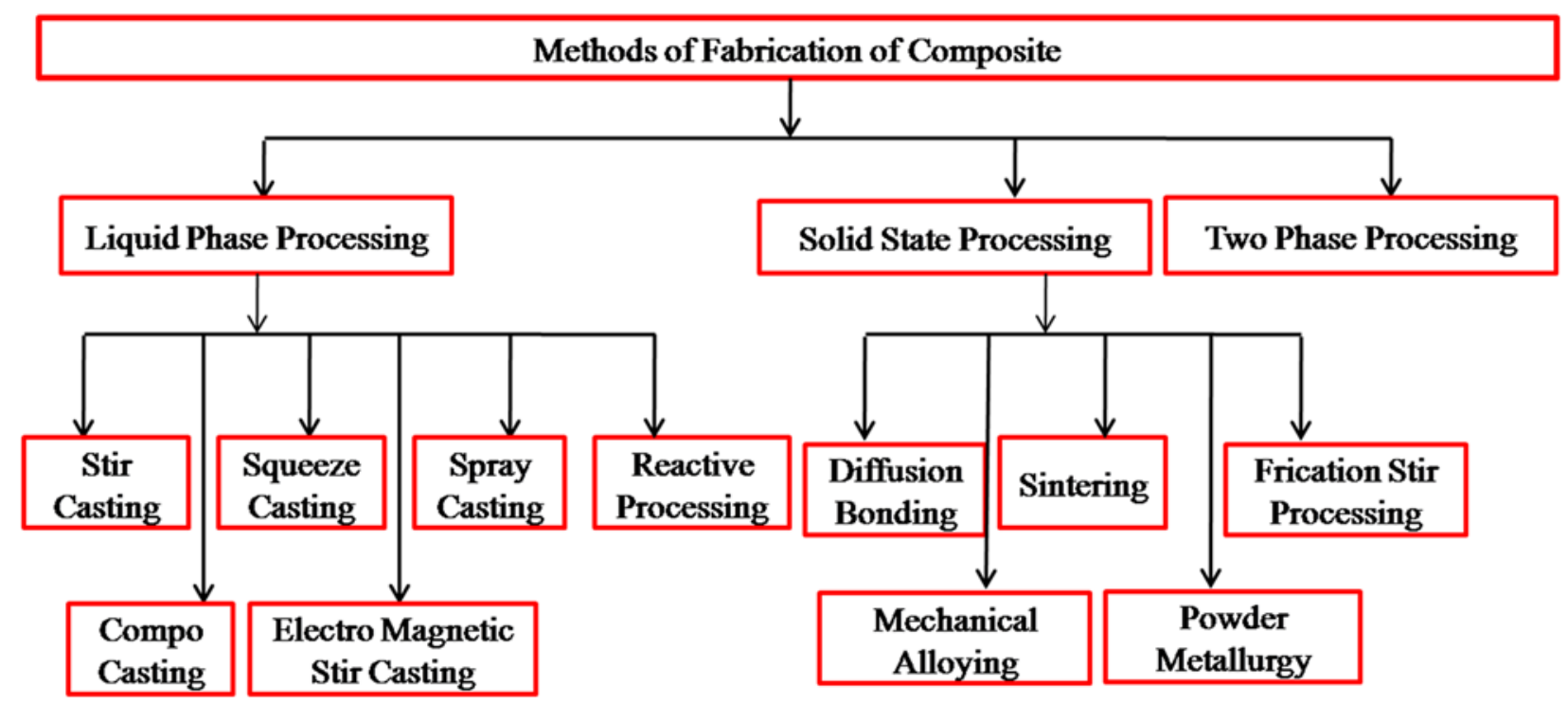

Fig. 1: Classification of Fabrication techniques for Metal Matrix Composite

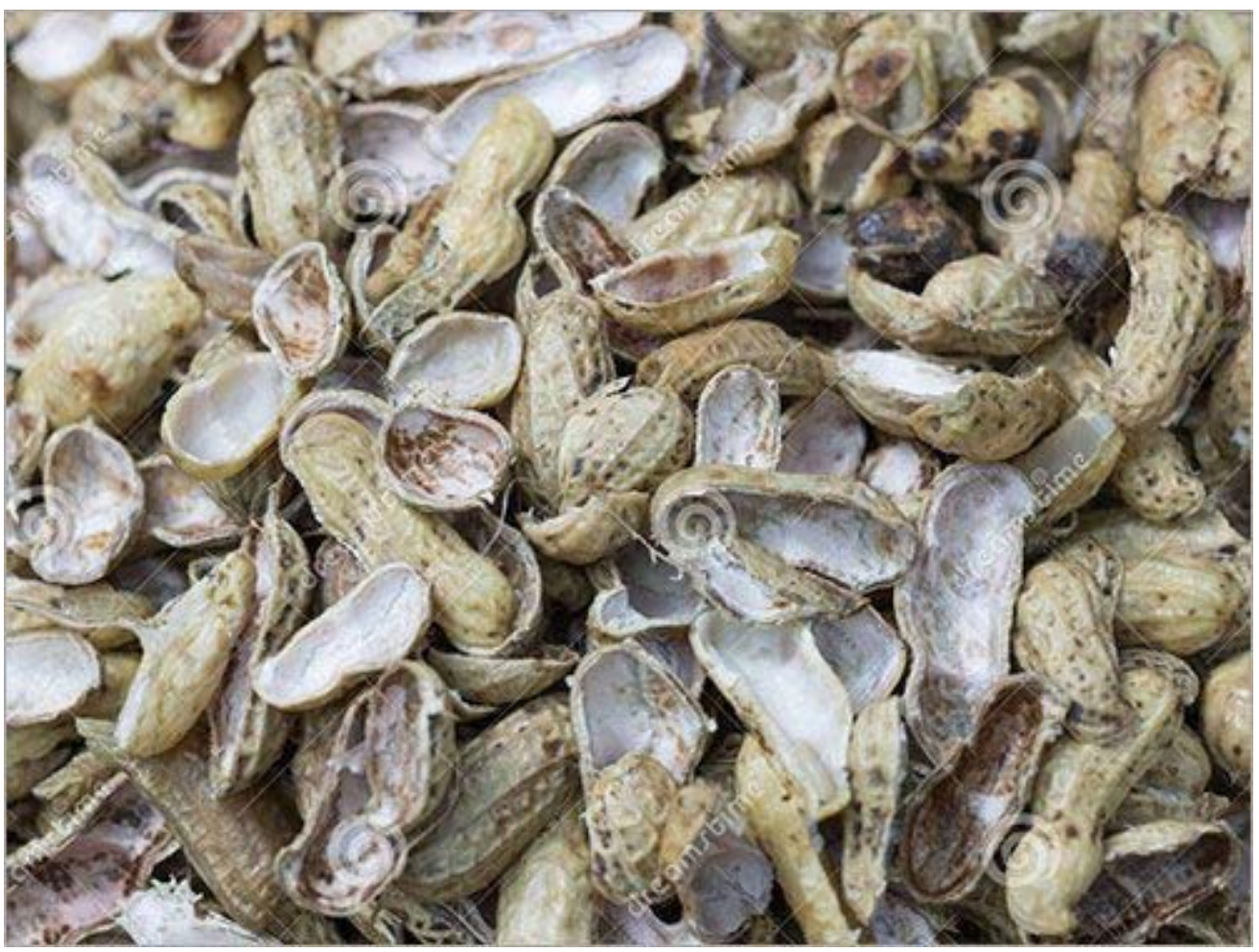

Fig. 2: Some photographs of Groundnut shell

Groundnut shell ash (GSA) is a product obtained from burning groundnut shells. GSA consists of considerable amount of refractory oxides and active silica $\left(\mathrm{SiO}_{2}\right)$ such as hematite $\left(\mathrm{Fe}_{2} \mathrm{O}_{3}\right)$ and Alumina $\left(\mathrm{Al}_{2} \mathrm{O}_{3}\right)$. It also contains small amount of alkalis and other trace elements ${ }^{8)}$. The chemical composition of GSA varies, depending on the geographic location, variety, and climate ${ }^{9-10)}$. Photographs of Groundnut shell waste (source from ADA BIO ENERGY) is shown in Fig. 2.

\subsection{Nano Reinforced Composites}

There is a growing body of evidence that composite materials containing a nano scale constituent have the potential to serve as a new generation of high performance and robust engineering materials. There is also a strong supposition that the thermal and electrical properties of some nano scale constituents could confirm these composite materials with secondary characteristics that will make them very attractive for a wide range of 
structures and platforms. Such materials could be fabricated either through incorporation of a nano-scale constituent as the reinforcing phase in a polymer matrix, or as an additional constituent to a continuous fiber/polymer matrix composite (i.e. a hierarchical composites). These nano-constituents can take a range of forms, but the research we have pursued here has been on using carbon nanotubes (CNTs) as a reinforcing phase. Research is underway worldwide to develop nanostructured and hierarchical composite materials. Over the last decade a number of researchers have attempted to incorporate nano constituents into bulk polymers using fairly direct approaches (such as simple mixing), with disappointing results. A particular hurdle has been the limited nano constituent loading fractions which can be achieved (under $1 \%$ by weight) before the composite becomes unprocessable. This has highlighted the need to consider the composite architecture in the material development process. However, over the last few years, considerable advances have been made in the material characterization methods to allow researchers to understand the interactions between the parent and nano scale constituents. Furthermore, advances in material modelling have provided the research community an insight into how to optimize the formulation of these materials. Presently there is a growing understanding of the issues which need to be addressed in order to bring these materials to a technical readiness level at which they can then be exploited and utilized by industry [11]. The next sub section will provide the detailed literature review.

\section{Development of Composite Material}

In this study, electromagnetic or mechanical stir casting technique is studied to fabricate the composites by various reinforcements. Traditional electromagnetic or mechanical stir casting technique is still preferred nowadays due to its simplicity, easiness and effective cost.

\section{Literature Review}

Large volume of work was earlier carried on development of metal matrix composites, hybrid metal matrix composite and nano-reinforced composite using various reinforcements via different casting technique. Keeping these facts in the mind, exhaustive literature review has been carried in the present wok and it has mainly been divided into four categories. Some of the important literature outcomes are summarized below for the development of GSA based reinforcement material with aluminium.

1. Literature Review of GSA as reinforcement

2. Literature Review of AA 2024 aluminium as a matrix material

3. Literature Review of Aluminium based Nano reinforced Composites

4. Literature review of Hybrid metal matrix composites

5. Literature review of various reinforcements in aluminium metal matrix composites

Table 1: Literature Review of GSA as reinforcement

\begin{tabular}{|c|c|c|c|c|}
\hline S.No. & $\begin{array}{l}\text { Materials } \\
\text { Used }\end{array}$ & Reinforcements & Conclusion and Results & $\begin{array}{l}\text { Ref. } \\
\text { No. }\end{array}$ \\
\hline 1 & $\begin{array}{l}\text { Polymer } \\
\text { composites }\end{array}$ & GSA & $\begin{array}{l}\text { Mixing of the reinforced content had increased the mechanical properties up to some } \\
\text { weight } \% \text { and with further increase of reinforced particles, the reduction of } \\
\text { characteristics was observed. }\end{array}$ & 7) \\
\hline 2 & $\begin{array}{l}(\mathrm{OPC}) \\
\text { concrete }\end{array}$ & GSA & $\begin{array}{ll}\text { Compressive strength of the GSA/OPC concrete was increased from } 29 \% \text { to } \\
40 \% \text { by the addition of } \text { GSA. }\end{array}$ & 8) \\
\hline 3 & $\begin{array}{l}\text { Groundnut } \\
\text { Shell Fiber }\end{array}$ & Epoxy resins & $\begin{array}{l}\text { Groundnut fiber, used as the matrix material had enhanced the physical and mechanical } \\
\text { properties. }\end{array}$ & 9) \\
\hline 4 & $\begin{array}{l}\text { Polymer } \\
\text { Composite }\end{array}$ & GSA and CSP & $\begin{array}{l}\text { Maximum tensile strength was obtained for the composite fabricated by reinforcing } \\
40 \% \text { vol. fraction CSP \&GSP volume fraction. Maximum flexural strength was } \\
\text { obtained for composite manufactured with } 50 \% \text { CSP\&GSP filled. }\end{array}$ & 10) \\
\hline 5 & $\begin{array}{l}\mathrm{Zn}-\mathrm{Al} \text { hybrid } \\
\text { composite }\end{array}$ & GSA & $\begin{array}{l}\text { The fracture toughness has been increased with the increase of GSA content in the } \\
\text { hybrid composite. }\end{array}$ & 11) \\
\hline 6 & $\begin{array}{l}\text { Aluminium } \\
6063\end{array}$ & GSA & Tensile strength increases up to $9 \%$ of reinforcement and then started decreasing. & 12) \\
\hline 7 & $\begin{array}{l}\text { Polyester } \\
\text { resin matrix }\end{array}$ & GSA & $\begin{array}{l}\text { This investigation has found that the } 15 \mathrm{Wt} . \% \text { groundnut shell reinforced polyester } \\
\text { composite exhibited the highest tensile strength. }\end{array}$ & 13) \\
\hline 8 & $\begin{array}{l}\text { Cement } \\
\text { Concrete } \\
\text { Cubes }\end{array}$ & Cement/GSA & $\begin{array}{l}\text { Experiment is evolved to determine optimum percentage of cement can be replaced } \\
\text { with ground nut shell ash pozzolona without sacrificing the strength mortar cubes. }\end{array}$ & 14) \\
\hline 9 & CBRPC and & GSA/Cow Bone & Mechanical properties of epoxy can be significantly enhanced by these reinforcements & 15) \\
\hline
\end{tabular}




\begin{tabular}{|c|c|c|c|c|}
\hline & GSRPC epoxy & & & \\
\hline 10 & $\begin{array}{l}\text { Polymer } \\
\text { composites }\end{array}$ & Al-Mg-Si alloy & The corrosion behavior of GSA reinforced composite was investigated. & 16) \\
\hline 11 & $\begin{array}{l}\text { Recycled } \\
\text { polyethylene } \\
\text { composite }\end{array}$ & GSA & $\begin{array}{l}\text { Alkaline treated GS powder had better-quality of mechanical properties for GSP- } \\
\text { recycled polyethylene composites, by mixing } 20 \% \text { weight fraction. }\end{array}$ & 17) \\
\hline 12 & $\begin{array}{l}\text { Aluminium } \\
\text { alloy }\end{array}$ & $\mathrm{GSA} / \mathrm{SiC}$ & $\begin{array}{l}\text { Mechanical properties was improved by for the } 6 \mathrm{Wt} . . \% \mathrm{Al}-\mathrm{Mg}-\mathrm{Si} / \mathrm{SiC}-\mathrm{GSA} \text { grades. } \\
\text { An improvement of } 15.7 \% \text { was attained, as compared to } 7.33 \% \text { accomplished by } 10 \\
\text { Wt.. \% composite grades. }\end{array}$ & 18) \\
\hline 13 & $\begin{array}{l}\text { Eichhornia } \\
\text { charcoal (EC) }\end{array}$ & Groundnut shells & $\begin{array}{l}\text { In this medical research paper, the adsorption of dye Basic Blue } 9 \text { (BB9) was } \\
\text { considered using groundnut shells charcoal and Eichhornia charcoal as adsorbents. }\end{array}$ & 19) \\
\hline 14 & Concrete & GSA & $\begin{array}{l}\text { The compressive strength of } 10 \% \text { replacement of GSA shows an increase of } 2.95 \% \\
\text { and } 1.21 \% \text { for } 7 \text { and } 28 \text { days respectively when compared to the conventional concrete. }\end{array}$ & 20) \\
\hline 15 & $\begin{array}{l}\text { Epoxy } \\
\text { Composites }\end{array}$ & GSA/RHA & $\begin{array}{l}\text { Samples consisting of GSA and RHA epoxy composites having } 2.5 \%, 5 \% .7 .5 \% \text {, } \\
10 \%, 12.5 \% \text { and } 15 \% \text { content of GSA and RHA were fabricated. } \\
\text { Outcomes of this research work showed that the GSA reinforced epoxy composites } \\
\text { had better mechanical properties in comparison to the RHA epoxy composites. }\end{array}$ & 21) \\
\hline
\end{tabular}

Table 2: Literature Review of AA 2024 aluminium as a matrix material

\begin{tabular}{|c|c|c|c|c|}
\hline S. No. & $\begin{array}{l}\text { Materials } \\
\text { Used }\end{array}$ & Reinforcements & Conclusion and Results & $\begin{array}{l}\text { Ref } \\
\text { No. }\end{array}$ \\
\hline 16 & $\mathrm{Al} 2024$ & SiC/Fly Ash & $\begin{array}{l}\mathrm{Al} / \mathrm{SiC}, \mathrm{Al} / \text { fly ash, } \mathrm{Al} / \mathrm{SiC} / \text { fly ash composites were positively manufactured by the two } \\
\text { step stir casting method. }\end{array}$ & 22) \\
\hline 17 & Al 2024 & $\begin{array}{l}\text { Fly ash and } \mathrm{E} \\
\text { glass fiber }\end{array}$ & $\begin{array}{l}\text { E-glass fiber \& fly ash had reduced the corrosion level from } 17 \mathrm{mpy} \text { to } 7 \mathrm{mpy} \text { for a } \\
\text { period of } 2 \text { days. }\end{array}$ & 23) \\
\hline 18 & Al 2024 & $\mathrm{MOS}_{2}$ & $\begin{array}{l}\text { Tensile Strength of } \mathrm{Al} 2024 / 4 \% \mathrm{MoS}_{2} \text { was maximum. Hardness was obtained to be } \\
\text { maximum for } \mathrm{Al} 2024 / 4 \% \mathrm{MoS}_{2} \text { composite }\end{array}$ & 24) \\
\hline 19 & AA 2024 & $\mathrm{SiC} / \mathrm{Gr}$ & $\begin{array}{l}\text { AA } 202410 \% \mathrm{SiC}+5 \% \mathrm{Gr} \text { composite consist of better hardness value as compare to base } \\
\text { metal. }\end{array}$ & 25) \\
\hline 20 & Al 2024 & $\mathrm{~B}_{4} \mathrm{C}$ & $\begin{array}{l}\text { Tensile strength and hardness was obtained to be maximum for } \mathrm{Al} 2024 / 5 \% \mathrm{~B}_{4} \mathrm{C} \\
\text { composite. }\end{array}$ & 26) \\
\hline 21 & AA 2024 & Fly ash & $\begin{array}{l}\text { Fracture toughness of AA2024 was in the range of } 17-18 \mathrm{MPa} \text { as compared to } 21 \mathrm{MP} \\
\text { for re-melted alloy AA2024. The JIC fracture toughness of composites was } 6-15 \mathrm{KJ} / \mathrm{m}^{2} \\
\text { as compared to } 25 \mathrm{KJ} / \mathrm{m}^{2} \text { for the re-melted AA } 2024 \text {. }\end{array}$ & 27) \\
\hline 22 & AA 2024 & Fly ash/ E-Glass & $\begin{array}{l}\text { UTS was improved with increase in reinforce content. E-glass fibre and fly ash resists } \\
\text { deforming stresses and improves the compressive strength of AA 2024/.Fly ash/ E- } \\
\text { Glass composite. }\end{array}$ & 28) \\
\hline 23 & AA 2024 & $\mathrm{~B}_{4} \mathrm{C} / \mathrm{Gr}$ & $\begin{array}{l}\text { The observed microstructure test revealed that alloying elements are distributed } \\
\text { homogeneously in aluminium matrix. } \mathrm{B}_{4} \mathrm{C} \text { and } \mathrm{Gr} \text { had enhanced the strength of the AA } \\
2024 \text {. }\end{array}$ & 29) \\
\hline 24 & AA 2024 & $\mathrm{SiC}$ & $\begin{array}{l}\text { Mechanical characterization had proved that there is enhancement in the mechanical } \\
\text { properties. }\end{array}$ & 30) \\
\hline 25 & AA 2024 & $\mathrm{~B}_{4} \mathrm{C}$ & $\begin{array}{l}\text { Wear in height loss was lower in case of AA2024-B4C composites as compared to base } \\
\text { AA2024. }\end{array}$ & 31) \\
\hline 26 & AA 2024 & $\begin{array}{l}\text { Tungsten } \\
\text { Carbide }\end{array}$ & $\begin{array}{l}\text { The reinforcement had improved the micro hardness and wear characteristics of } \\
\text { fabricated composite. }\end{array}$ & 32) \\
\hline 27 & AA 2024 & pure $\mathrm{Cu}$ & $\begin{array}{l}\text { Microstructural examination of a dissimilar AA2024 to pure } \mathrm{Cu} \text { joint made by linear } \\
\text { friction welding was observed. }\end{array}$ & 33) \\
\hline 28 & $\begin{array}{l}\text { Al } 2024 \\
\text { alloy }\end{array}$ & $\mathrm{SiC}+\mathrm{Gr}$ & $\begin{array}{l}\text { The tensile strength and yield stress was increased. Elongation was reduced as the volume } \\
\text { fraction of } \mathrm{SiC} \text { content was reduced. Interfacial bonding of } \mathrm{Gr} / \text { matrix and } \mathrm{SiC} / \mathrm{matrix} \text { had } \\
\text { enhanced the relative homogeneity in the fabricated composite. }\end{array}$ & 34) \\
\hline 29 & $\begin{array}{l}\text { Al } 2024 \\
\text { alloy }\end{array}$ & $\begin{array}{l}\mathrm{Al}_{2} \mathrm{O}_{3} \quad \text { nano } \\
\text { composite }\end{array}$ & $\begin{array}{l}\mathrm{Al} 2024 / \mathrm{Al}_{2} \mathrm{O}_{3} \text { nanoparticles was positively made by compo casting method followed by } \\
\text { FSP. }\end{array}$ & 35) \\
\hline 30 & $\begin{array}{l}\text { Al } 2024 \\
\text { alloy }\end{array}$ & $\mathrm{B}_{4} \mathrm{C}$ & $\begin{array}{l}\text { UTS and YS of } \mathrm{Al} 2024 / \mathrm{B}_{4} \mathrm{C} \text { composite was improved whereas percentage elongation } \\
\text { of the composites was decreased by the increase of the order of boron carbide. }\end{array}$ & 36) \\
\hline
\end{tabular}




\begin{tabular}{|l|l|l|l|l|}
\hline & & & & \\
\hline 31 & Al 2024 & SiC - Graphene & $\begin{array}{l}\text { Al2024-SiC-Graphene hybrid nano composite was developed by ultrasonic liquid } \\
\text { processing (ULP) technique }\end{array}$ & 37) \\
\hline
\end{tabular}

Table 3: Literature Review of Aluminium based Nano reinforced Composites

\begin{tabular}{|c|c|c|c|c|}
\hline S. No & Alloy & Reinforcement & Result & Ref. \\
\hline 32 & Al 356 & Nano-SiC particles & $\begin{array}{l}\text { A356 /nano-SiC composite was fabricated by stir casting method. } \mathrm{SiC} \\
\text { content was distributed uniformly within the matrix. Mixing of } 4.5 \text { vol. } \% \\
\text { of } \mathrm{SiC} \text { had improved the UTS from } 145 \text { to } 240 \mathrm{MPa} \text {. }\end{array}$ & 38) \\
\hline 33 & AA 7075 & Nano $\mathrm{SiC}$ particles & $\begin{array}{l}\text { AA } 7075 / \mathrm{SiC} \text { nano composites were manufactured by mechanical stirring } \\
\text { and ultrasonic cavitation process. Hardness and impact strength of AA } \\
7075 / 10 \% \mathrm{SiC} \text { nano composite was improved by } 10 \% \text { and } 75 \% \\
\text { respectively. }\end{array}$ & 39) \\
\hline 34 & $\mathrm{Al} 6061$ & $\mathrm{Nano} \mathrm{Al}_{2} \mathrm{O}_{3}$ particles & $\begin{array}{l}\mathrm{Al} 6061 / \mathrm{Al}_{2} \mathrm{O}_{3} \text { composite was prepared by ultrasonic assisted squeeze } \\
\text { casting method with avoiding the accumulation of } \mathrm{Al}_{2} \mathrm{O}_{3} \text { particulates. }\end{array}$ & 40) \\
\hline 35 & Pure Al & $\mathrm{TiO}_{2}$ nanoparticles & $\begin{array}{l}\mathrm{Al} / \mathrm{TiO}_{2} \text { nano composite specimen was manufactured via powered stir } \\
\text { casting technique with avoiding agglomeration of } \mathrm{TiO}_{2} \text { nanoparticles. }\end{array}$ & 41) \\
\hline 36 & Al 6061 & Nano $\mathrm{ZrO}_{2}$ content & $\begin{array}{l}\text { Aluminium- } \mathrm{ZrO}_{2} \text { nano composites } 7.5 \% \text { successfully produced by stir } \\
\text { casting method. }\end{array}$ & 42) \\
\hline 37 & Al 2219 & $\begin{array}{l}\text { Nano silicon carbide } \\
(\mathrm{SiC}) \text { particles }\end{array}$ & $\begin{array}{l}\text { AA } 2219 / \mathrm{SiC} \text { nano composite was prepared via ultrasonic assisted stir } \\
\text { casting method. }\end{array}$ & 43) \\
\hline 38 & AZ31 & $\begin{array}{l}\text { Graphene nano } \\
\text { platelets (GNP) }\end{array}$ & $\begin{array}{l}\text { The AZ31-GNPs composite was fabricated by using stir-casting method } \\
\text { followed by hot extrusion. The mechanical testing at room temperature had } \\
\text { depicted the enhancement in mechanical properties. }\end{array}$ & 44) \\
\hline 39 & Pure aluminum & Nano $\mathrm{TiO}_{2}$ & $\begin{array}{l}\text { The powder metallurgy method was used to prepare } \mathrm{Al} / \mathrm{TiO}_{2} \text { composite } \\
\text { successfully. Uniform distribution of 40reinforcement was observed. }\end{array}$ & 45) \\
\hline 40 & Al-SiC alloy & $\mathrm{Al}_{2} \mathrm{O}_{3}-\mathrm{WS}_{2}$ & $\begin{array}{l}\text { Increased Wt. \% of } \mathrm{WS}_{2} \text { solid lubricant had increased the hardness of the } \\
\text { hybrid composite. The } \% \text { of WS } 2 \text { had increased the density of the } \\
\text { composite by filling the gap of the composite. Composites with about } 5 \\
\text { percent of } \mathrm{WS}_{2} \text { have less pits and worn out surface as compare to composite } \\
\text { without } \mathrm{WS}_{2}\end{array}$ & 46) \\
\hline 41 & AZ91E & $\mathrm{Al}_{2} \mathrm{O}_{3}$ & $\begin{array}{l}\mathrm{AZ} 91 \mathrm{E} / \mathrm{Al}_{2} \mathrm{O}_{3} \text { composite was prepared by Semi Solid stir casting method } \\
\text { with varied weight percentages. AZ91E/ } 2 \mathrm{Wt} . \% \mathrm{Al}_{2} \mathrm{O}_{3} \text { composite had } \\
\text { improved mechanical properties than other varied reinforcements. Macro } \\
\text { hardness and tensile strength was enhanced by } 22.5 \% \text { and } 26.54 \% \text {. }\end{array}$ & 47) \\
\hline 42 & AA 7075 & $\begin{array}{l}\mathrm{SiC}+\mathrm{Al}_{2} \mathrm{O}_{3} \\
\text { Nano composites }\end{array}$ & $\begin{array}{l}\text { Single and hybrid reinforced nano composites was manufactured via stir } \\
\text { and squeeze cast process. Hardness was enhanced by } 63.7 \% \text { and } 81.1 \% \text { for } \\
\text { single and hybrid reinforced nano composite. }\end{array}$ & 48) \\
\hline
\end{tabular}

Table 4: Literature review of various reinforcements in aluminium metal matrix composites

\begin{tabular}{|l|l|l|l|l|l|}
\hline S. No. & Materials & Percent Reinforcements & Hardness & Tensile Strength & Ref. No \\
\hline 43 & Al 6061 & $8 \mathrm{Wt} . \% \mathrm{SiC}$ & $51 \mathrm{HRB}$ & $298 \mathrm{MPa}$ & $49)$ \\
\hline 44 & A 359 & $8 \mathrm{Wt} \% \mathrm{Al}_{2} \mathrm{O}_{3}$ & $148.7 \mathrm{BHN}$ & $148.7 \mathrm{~N} / \mathrm{mm}^{2}$ & $50)$ \\
\hline 45 & A 356 & $7.5 \mathrm{Wt} \% \mathrm{Al}_{2} \mathrm{O}_{3}$ & $78 \mathrm{BHN}$ & $164 \mathrm{MPa}$ & $51)$ \\
\hline 46 & A 356 & $5 \mathrm{Wt} \% \mathrm{SiC}^{2}$ & $104.66 \mathrm{BHN}$ & $309.83 \mathrm{MPa}$ & $52)$ \\
\hline 47 & Aluminium & $7 \mathrm{Wt} \% \mathrm{Al}_{2} \mathrm{O}_{3}$ & $63 \mathrm{BHN}$ & $120 \mathrm{MPa}$ & $53)$ \\
\hline 48 & Aluminium & $15 \mathrm{Wt} . \% \mathrm{SiC}$ & $52 \mathrm{BHN}$ & $145 \mathrm{MPa}$ & $54)$ \\
\hline 49 & Aluminium & $6 \& 10 \mathrm{Wt} \% \mathrm{GSA}, \mathrm{SiC}$ & $63 \mathrm{HRV}$ & $166 \mathrm{MPa}$ & $55)$ \\
\hline 50 & Aluminium & $10 \mathrm{Wt} \% \mathrm{SiC}$ & $147.2 \mathrm{VHN}$ & 163 & $56)$ \\
\hline
\end{tabular}




\begin{tabular}{|c|c|c|c|c|c|}
\hline 51 & Aluminium & $6 \mathrm{Wt} . \% \mathrm{SiC}$ & $88 \mathrm{HV}$ & $130 \mathrm{MPa}$ & 57) \\
\hline 52 & Aluminium & $20 \mathrm{Wt} . \% \mathrm{SiC}$ & $45.40 \mathrm{BHN}$ & $77.56 \mathrm{MPa}$ & 58) \\
\hline 53 & AA 5083 & $10 \mathrm{Wt} . \% \mathrm{SiC}$ & $76 \mathrm{BHN}$ & $253 \mathrm{MPa}$ & 59) \\
\hline 54 & LM 25 & $\begin{array}{l}10 \% \text { mica \& } 10 \% \text { activated } \\
\text { Carbon }\end{array}$ & $89.5 \mathrm{BHN}$ & & $60)$ \\
\hline 55 & LM 6 & $10 \mathrm{Wt} . \% \mathrm{SiC}$ & $78 \mathrm{BHN}$ & & 61) \\
\hline 56 & Al 6061 & $12 \mathrm{Wt} . \% \quad \mathrm{Al}_{2} \mathrm{O}_{3}$ & $185 \mathrm{BHN}$ & $195 \mathrm{MPa}$ & $62)$ \\
\hline 57 & $\mathrm{Al} 6061$ & $\mathrm{NiP}$ coated $10 \mathrm{Wt} . \% \mathrm{Si}_{3} \mathrm{~N}_{4}$ & $86.6 \mathrm{BHN}$ & $306 \mathrm{MPa}$ & 63) \\
\hline 58 & AA 6061 & $10 \mathrm{Wt} . \% \quad \mathrm{~B}_{4} \mathrm{C}$ & $68 \mathrm{HV}$ & $145 \mathrm{MPa}$ & $64)$ \\
\hline 59 & AA 6061 & 15Wt.\% TiC & & $230 \mathrm{MPa}$ & $65)$ \\
\hline 60 & AA 6063 & $12 \% \mathrm{Al}_{2} \mathrm{O}_{3} \& 1 \% \mathrm{Gr}$ & & $351.6 \mathrm{MPa}$ & $66)$ \\
\hline 61 & $\mathrm{Al} 6082$ & $12 \mathrm{Wt} . \% \mathrm{Si}_{3} \mathrm{~N}_{4}$ & $93.5 \mathrm{VHN}$ & $201 \mathrm{MPa}$ & $67)$ \\
\hline 62 & AA 6082 & $10 \% \mathrm{Wt} . \mathrm{WC}$ & 83BHN & $190 \mathrm{~N} / \mathrm{mm}^{2}$ & $68)$ \\
\hline 63 & LM 25 & $2 \mathrm{wt} \% \mathrm{Al}_{2} \mathrm{O}_{3}, 3 \mathrm{wt} \% \mathrm{~B}_{4} \mathrm{C}$ & $52.8 \mathrm{BHN}$ & $54.6 \mathrm{MPa}$ & 69) \\
\hline 64 & Al 7075 & $10 \mathrm{Wt} . \% \mathrm{SiC}$ & $229.9 \mathrm{MPa}$ & $110 \mathrm{BHN}$ & $70)$ \\
\hline 65 & AA 6061 & 5Wt. \% Cenosphere & $57 \mathrm{VHN}$ & $0.075 \mathrm{KN} / \mathrm{mm}^{2}$ & 71) \\
\hline
\end{tabular}

\section{Summary and discussion}

Utilization of groundnut shell as reinforcement is an interesting research area in the development of various composite materials. However, utilization of GSA as reinforcement in the development of concrete based composite material has been carried out by various researchers is shown in Table 1. Very few researchers have tried to utilize GSA with aluminum alloy.

Fig. 3 shows the summary of reported work GSA as reinforcement for the development of different types of composite. It can be observed that GSA was utilize as reinforcement for the development of polymer based composite about $53 \%$. In the development of cement concrete based composite GSA was used about $27 \%$. However, only about $20 \%$ GSA was used as reinforcement material for the development of metal matrix composite.

Nowadays, aluminum copper based alloy AA 2024 based composite is highly demanding material in the automotive industries due to high strength to weight ratio. Fig. 4 shows the summary of reinforcement material used for development of AA 2024 based metal matrix composite. It can be observed that most of the researchers have used flash and $\mathrm{SiC}$ as a reinforcement to enhance mechanical properties of AA 2024 alloy. However, very fewer efforts have been made to understand the effect of pure $\mathrm{Cu}, \mathrm{WC}$ and MOS2 on mechanical behavior of AA 2024 based composite. Table 2 shows the summary of reported work of various reinforcement materials for the development of AA 2024 based composite material.

Fig. 5 shows the summary of percentage contribution of various reinforcement material used for the development of metal matrix composite. The details of reported work related to various reinforcement material presented by various researchers is provided in Table 4.

Furthermore, through literature survey it was found that Kenaf/E-glass ${ }^{72)}, \mathrm{SiC}^{73-74)}$ and uncarbonized egg shell ${ }^{75)}$ particles were successfully used to develop composite through stir casting techniques. 


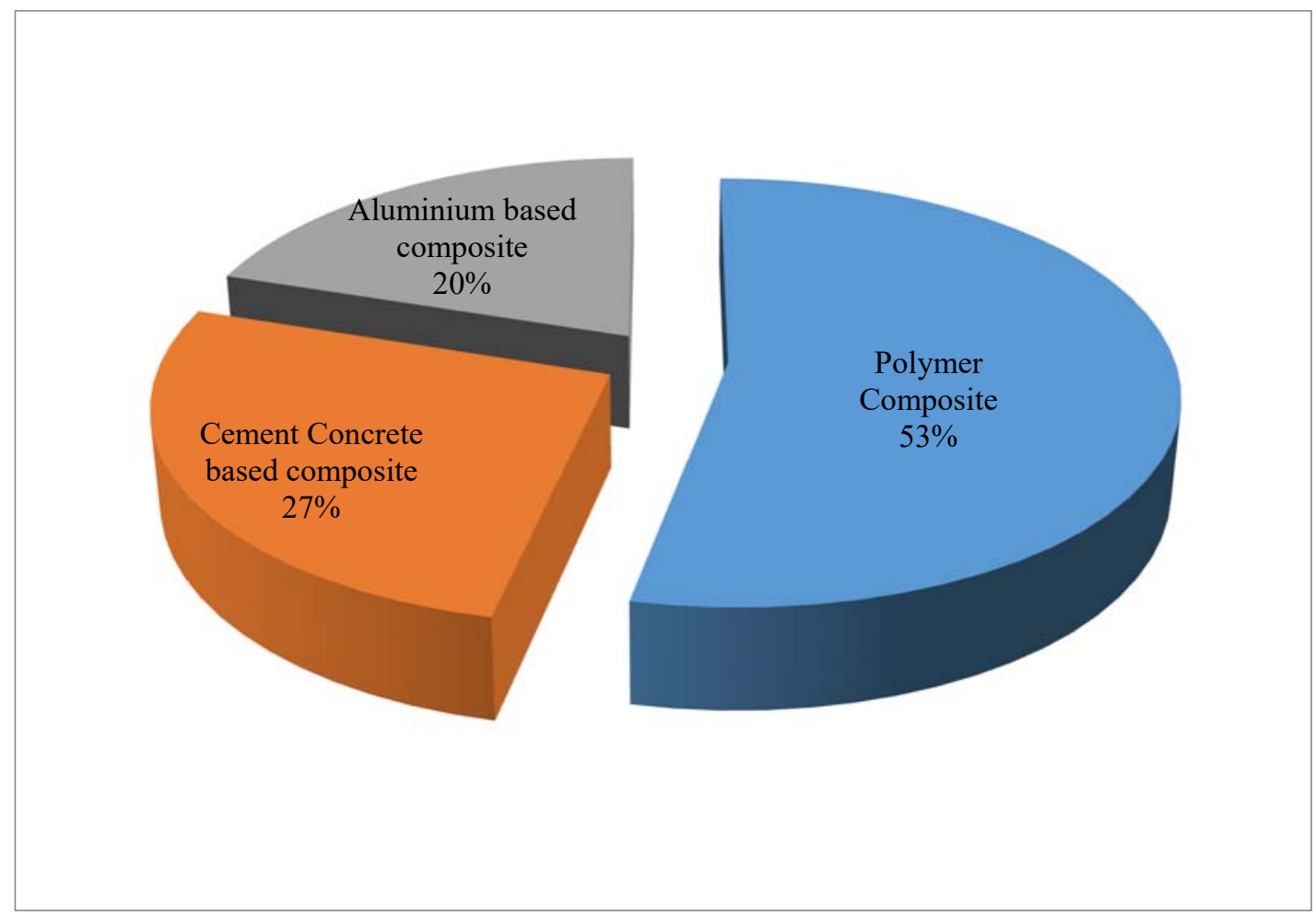

Fig 3: Summary of reported work GSA as reinforcement for the development of different types of composite

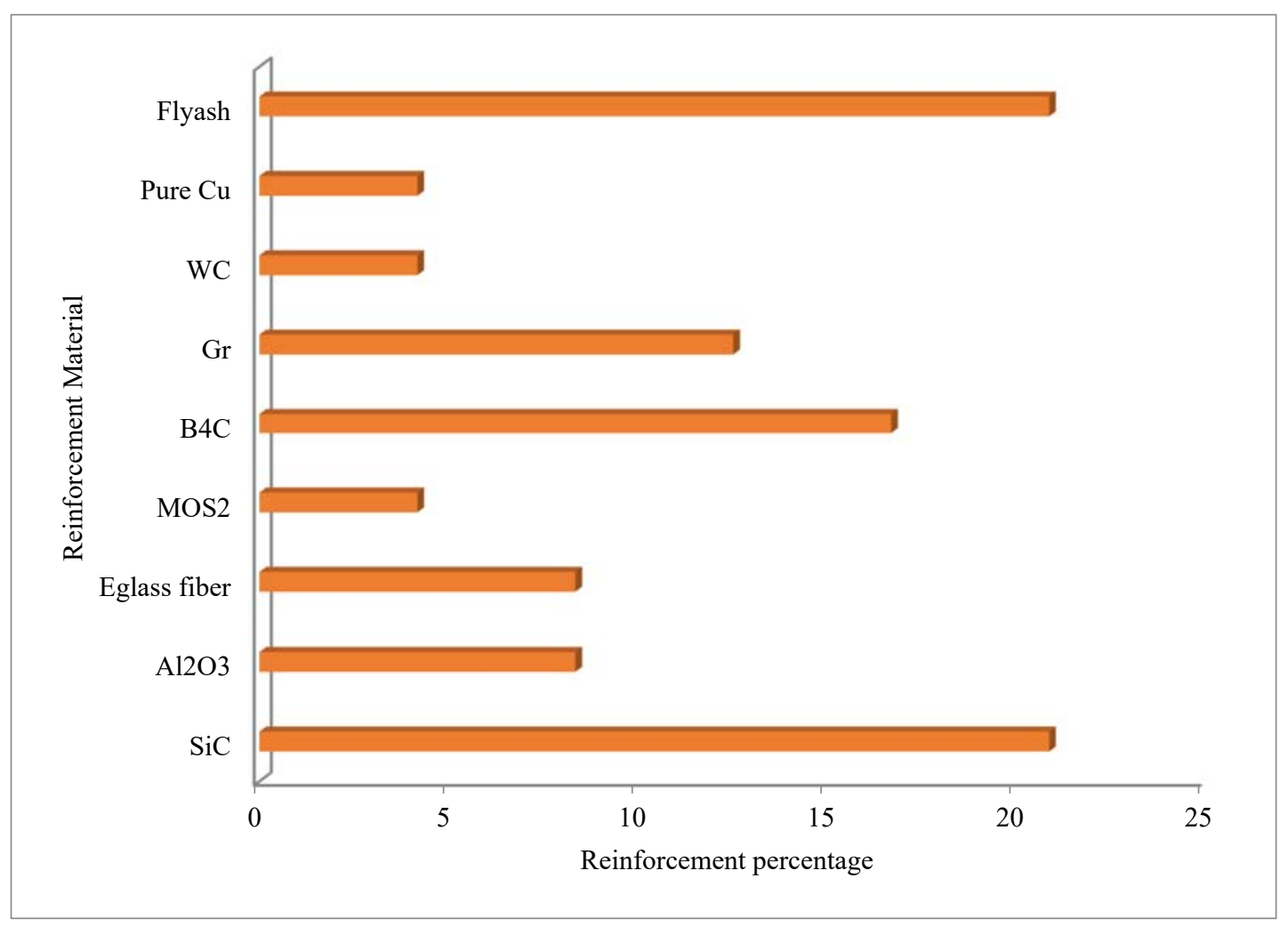

Fig 4: Summary of reinforcement material used for AA 2024 based metal matrix composite 


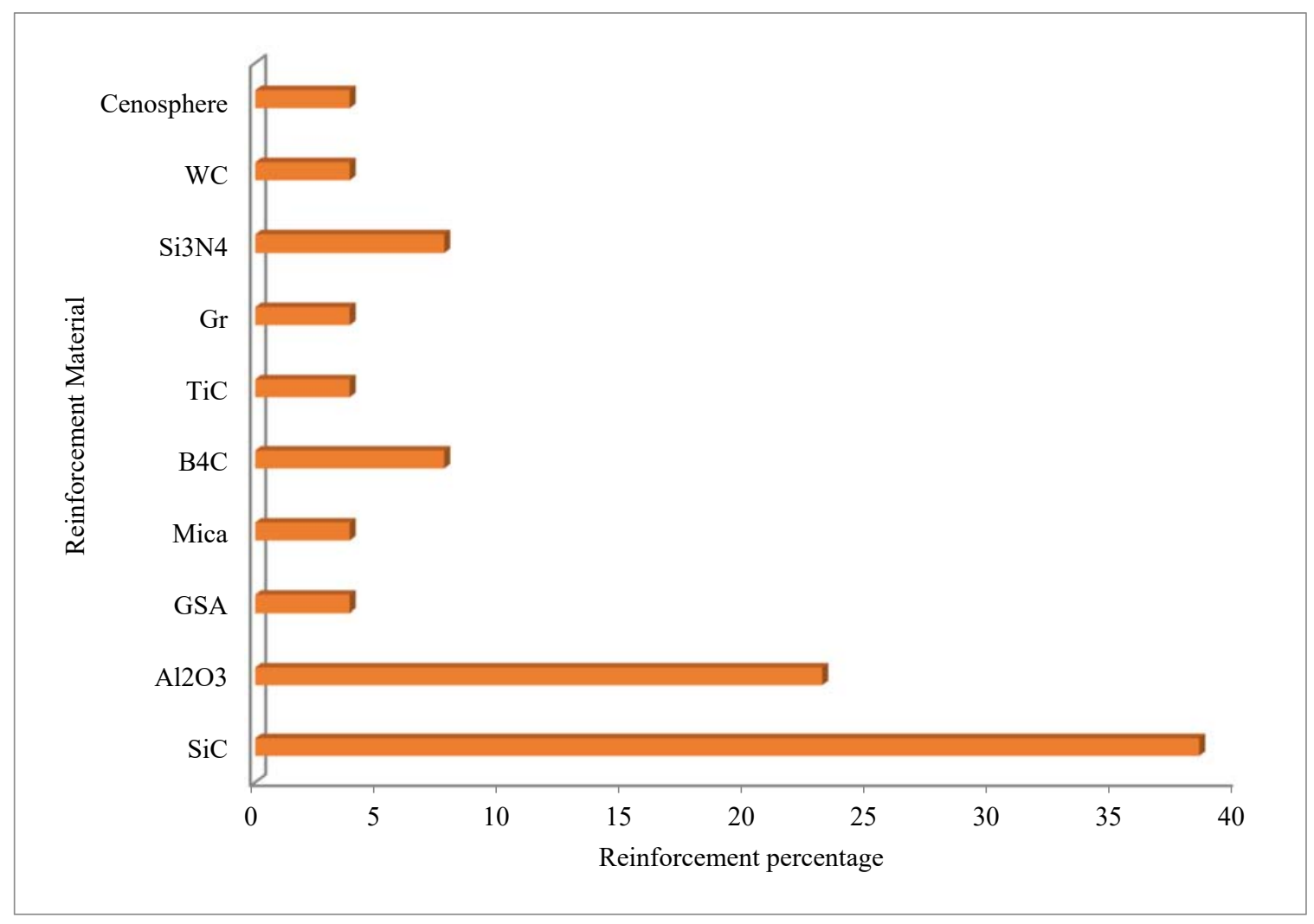

Fig 5: Summary of percentage of reinforcement material used for the development of metal matrix composite

\section{Conclusions}

After the exhaustive review of literature it was observed that waste groundnut shell (agricultural residues) is inexpensive and valuable biopolymers, which can be used as reinforcement for the development of the metal matrix composite. The following observations of this research work can be concluded as follows.

- It was observed that GSA was successfully used as a reinforcement for the development of various composite like metal matrix composite, cement concrete based composite and polymer composite.

- AA 2024 alloy with various combinations of reinforcements developed by various stir casting method to find out its mechanical and tribological characteristics. Though in all cases tensile strength, hardness, fatigue strength improved, but toughness is reduced. Decrement of toughness cannot be ignored.

- From the literature, it can be observed that by using GSA as a reinforcement material, overall toughness can be improved. But very few researchers used GSA as reinforcement material in the development of aluminium base composite.

- A lot of work has been carried out for AA 2024 aluminium alloy using various reinforcement such as $\mathrm{SiC}, \mathrm{Al}_{2} \mathrm{O}_{3}, \mathrm{~B}_{4} \mathrm{C}$, fly-ash, Rice Husk Ash, graphite. But very few works has been carried out for AA 2024 aluminium alloy using GSA as reinforcement.

\section{References}

1) S. P. Dwivedi, N.K. Maurya, M. Maurya, Assessment of Hardness on AA 2014/Eggshell composite Produced Via Electromagnetic Stir Casting Method, EVERGREEN Joint Journal of Novel Carbon Resource Sciences \& Green Asia Strategy, 06, 285 (2019).

2) M. Maurya, Sudhir Kumar, and Vivek Bajpai, Assessment of the mechanical properties of aluminium metal matrix composite: A review, Journal of Reinforced Plastics and Composites,38, 267 (2019).

3) M. Maurya, Nagendra Kumar Maurya, Fabrication of A359 Alloy Reinforced With B4C Particulates \&Characterization of Mechanical Properties, International Journal of Advance Research in Science and Engineering, 6, 532 (2017).

4) P. Pirhayati, H.J. Aval, Effect of silver on non-isothermal aging of friction surfaced AA 2024-16wt\% Ag composites, Surface and Coating Technology (2019) doi: https://doi.org/10.1016/j.surfcoat.2019.125059.

5) M. Maurya, S. Kumar, V. Bajpai and N. K. Maurya, Process parameters, development and applications of stir cast composite: A review, Materials Testing, 62 (2020) 2, DOI $10.3139 / 120.111472$

6) S. P. Dwivedi, S. Sharma, R. K. Mishra, Characterization of waste eggshells and $\mathrm{CaCO} 3$ reinforced AA 2014 green metal matrix composites: A green approach in the synthesis of composites, International Journal of Precision Engineering and Manufacturing,17, 1383(2016). 
7) G. U. Raju, S. Kumarappa, V. N. Gaitonde, Mechanical and physical characterization of agricultural waste reinforced polymer composites, J. Mater. Environ. Sci. 3, 5 (2012).

8) T.C. Nwofor and S. Sule, Stability of groundnut shell ash (GSA)/ordinary portland cement (OPC) concrete in Nigeria, Advances in Applied Science Research,3, 2283(2012).

9) A. Lakshumu Naidu, B. Sudarshan, K. Hari Krishna, Study On Mechanical Behavior Of Groundnut Shell Fiber Reinforced Polymer Metal Matrix Composites, International Journal of Engineering Research \& Technology (IJERT) ,2,(2013).

10) S. Muthukumar, K. Lingadurai, Investigating the mechanical behaviour of coconut shell and groundnut shell reinforced polymer composite, Global Journal Of Engineering, Science And Researches,19,(2014).

11) K.K. Alaneme, B.O. Fatile a, J.O. Borode, Mechanical and Corrosion Behavior of Zn-27Al Based Composites Reinforced with Groundnut Shell Ash and Silicon Carbide, Tribology in Industry,36, 195 (2014) .

12) Jagdeep Singh, N.M. Suri, Ajay Verma, Affect of mechanical properties on groundnut shell ash reinforced AL 6063, International Journal for Technological Research in Engineering, 2, (2015).

13) M.N. Prabhakar, Atta ur rehman Shah, Jung-Il Song, Thermal and Mechanical Properties of Waste Ground Nutshell Reinforced Polyester Composites, Changwon National University,28, 118 (2015).

14) Narayana Moorthi V,Muthu Mariappan P,Dr. Kuppusamy K A, A study on Strength of Cement Mortar with Partial Replacement of Groundnut Shell Ash, Singaporean Journal of Scientific Research(SJSR)7,380(2015) .

15) O. I. Rufai, G. I. Lawal, B. O. Bolasodun, S. I. Durowaye, J. O. Etoh, Effect of Cow bone and Groundnut Shell Reinforced in Epoxy Resin on the Mechanical Properties and Microstructure of the Composites, International Journal of Chemical, Molecular, Nuclear, Materials and Metallurgical Engineering,9(2015).

16) Kenneth Kanayo Alaneme, Henry Ikechukwu EZE, Michael Oluwatosin Bodurin, Corrosion behaviour of groundnut shell ash and silicon carbide hybrid reinforced Al-Mg-Si alloy matrix composites in $3.5 \% \mathrm{NaCl}$ and $0.3 \mathrm{M}$ $\mathrm{H} 2 \mathrm{SO} 4$ solutions, Leonardo Electronic Journal of Practices and Technologies,26,129(2015).

17) Mohammed Awwalu Usman, Ibrahim Momohjimoh, Abdulahi S. B. Gimba, Effect of Groundnut Shell Powder on the Mechanical Properties of Recycled Polyethylene and Its Biodegradability, Journal of Minerals and Materials Characterization and Engineering,4, 228(2016).

18) Kenneth Kanayo Alaneme, Michael Oluwatosin Bodunrin, Adebimpe A. Awe, Microstructure, mechanical and fracture properties of groundnut shell ash and silicon carbide dispersion strengthened aluminium matrix composites, Journal of King Saud University - Engineering Sciences,30,96 (2018).

19) Sumanjit, Seema Rani, R.K. Mahajan, Equilibrium, kinetics and thermodynamic parameters for adsorptive removal of dye Basic Blue 9 by groundnut shells and Eichhornia, Arabian Journal of Chemistry, 9, S1464(2016).

20) Dharani D Arivu Thiravida Selvan V, Durability Studies on Concrete by using Groundnut Shell Ash as Mineral Admixture, IJIRST -International Journal for Innovative Research in Science \& Technology,3, 2349 (2017).

21) Akindapo Jacob Olaitan, AGOV Emmanuel Terhemen, GARBA Danladi King, OGABI Rapheal Oluwatoyin, Comparative Assessment of Mechanical Properties of Groundnut Shell and Rice Husk Reinforced Epoxy Composites, American Journal of Mechanical Engineering,3, 76(2017).

22) M. Boopathi, M., K.P. Arulshri and N. Iyandurai, Evaluation of mechanical properties of aluminium alloy 2024 reinforced with silicon carbide and fly ash hybrid metal matrix composites, American Journal of Applied Sciences,3,219(2013).

23) Prabhakar Bandeppa Kammar, H. K. Shivanand, Santhosh Kumar. S, Evaluation of corrosion properties of al 2024 based hybrid mmc's, International Journal of Advances in Engineering \& Technology,5, 132 (2013).

24) Bhargavi Rebba, N. Ramanaiah, Evaluation of Mechanical Properties of Aluminium Alloy (Al-2024) Reinforced with Molybdenum Disulphide (MOS2) Metal Matrix Composites, Procedia Materials Science,6, 1161(2014).

25) Marlon jones louis, Fabrication, testing and analysis of aluminium 2024 metal matrix composite, International journal of research in aeronautical and mechanical engineering, 2,29 (2014).

26) Bhargavi Rebba, N. Ramanaiah, Studies on Mechanical Properties of $2024 \mathrm{Al}$ - B4c Composites, Advanced Materials Manufacturing \& Characterization, 4(2014).

27) Ajit Bhandakkar, R C Prasad, Shankar M L Sastry, Fracture Toughness of AA2024 Aluminum Fly Ash Metal Matrix Composites, international Journal of Composite Material, 4, 108(2014).

28) Preetam Kulkarni, Evaluation of Mechanical Properties of AL 2024 Based Hybrid Metal Composites, IOSR Journal of Mechanical and Civil Engineering,12, 108(2015).

29) Vijayaraghavan K, Arul Kumar A , Dr. Amos Robert Jayachandran J, Subramani N, Analysis on Aluminium Metal Matrix Composites with Boron Carbide and Graphite, International Journal of Innovative Research in Science, Engineering and Technology, 5 (2016).

30) Atul Kumar, Sudhir Kumar \& Rohit Garg, Production \& characterization of al 2024-sicp metal matrix composite using stir casting, Journal of Mechanical and Production Engineering (JMPE),6,2278(2016).

31) Shivananda B K, Madeva Nagaral,D Madhu, V Auradi, Studies on wear behavior of AA2024-B4C composites, International Journal of Engineering Research, 5, 1129 (2016).

32) Abhijith R, Harish. T. M, Fabrication \& Analysis of Aluminium (Al-2024) and Tungsten Carbide (WC) Metal Matrix Composite by in-Situ Method" International Journal of Engineering Research \& Technology (IJERT),5 (2016). 
33) M.-N.Avettand-Fènoël, G.Racineux, L. Debeugny, R. Taillard, Microstructural characterization and mechanical performance of an AA2024 aluminium alloy-Pure copper joint obtained by linear friction welding, Materials \& Design,98 , 305(2016).

34) Cheng-jin $\mathrm{HU}$,Microstructures and mechanical properties of $2024 \mathrm{Al} / \mathrm{Gr} / \mathrm{SiC}$ hybrid composites fabricated by vacuum hot pressing, Transaction of Non Ferrous Metals Society of China, 26,1259(2016).

35) Wael Hoziefa P, Amir A. Mahdy P P, M.M.Z. Ahmed P P, I. El-Mahallawi P P, A. Atlam, Influence of friction stir processing rotational speed on microstructure and mechanical properties of AA2024 nanocomposite, International Journal of Scientific\& Engineering Research, 7(2016).

36) R Madeva Nagaral Pavan. Shilpa P. S. V. Auradi, Tensile Behavior of B4C Particulate Reinforced A12024 Alloy Metal Matrix Composites, FME Transactions,45, 93(2017).

37) Prashantha Kumar H.G Anthony Xavior .M, Assessment of mechanical and tribological properties of al 2024- SiCGraphene hybrid composites, Global Congress on Manufacturing and Management Procedia Engineering,174,992(2017).

38) Ali Mazahery, Mohsen Ostad Shabani, Plasticity and microstructure of A356 matrix nano composites, Journal of King Saud University - Engineering Sciences, 25, 41(2013).

39) Dr. Govind Nandipati, Dr. Ravindra Kommineni, Dr. Nageswara Rao Damera, Study on Processing and Mechanical Properties of nano SiCp reinforced AA7075, The International Journal Of Engineering And Science (IJES),3,2319 (2014).

40) Mayuresh Singh, R.S. Rana, Rajesh Purohit, krishnkant sahu, Development and Analysis of Al-Matrix Nano Composites fabricated by ultrasonic assisted Squeeze casting process, Materials Today: Proceedings,2,3697 ( 2015 ).

41) Adil Nazaruddin, T. S. Krishna kumar, Effect of Addition of Nanoparticles on the Mechanical Properties of Aluminium, International Journal of Engineering Research \& Technology (IJERT),4 (2015).

42) M Ramchndra, G Dilip Maruthi, R Rashmi, Evaluation of corrosion property of Aluminium Zirconium Oxide nano composites. World Academy of Science, Engineering and Technology, International Journal of Chemical, Molecular, Nuclear, Materials and Metallurgical Engineering,10,(2016)

43) N V Murthy, A Prasad Reddy, N Selvaraj, C S P Rao, Preparation of $\mathrm{SiC}$ based Aluminium metal matrix nano composites by high intensity ultrasonic cavitation process and evaluation of mechanical and tribological properties, IOP Conf. Series: Materials Science and Engineering, 149 (2016) .

44) Muhammad Rashad, Fusheng Pan, Yanglu Liu, Xianhua Chen, Han Lin, Rongjian Pan, Muhammad Asif, Jia She, High temperature formability of grapheme nanoplateletsAZ31 composites fabricated by stir-casting method, Journal of Magnesium and Alloys, 4, 270 (2016).
45) Amal E. Nassar, Eman E. Nassar, Properties of aluminum matrix Nano composites prepared by powder metallurgy processing, Journal of King Saud University -Engineering Sciences, 29, 295 (2017).

46) Navdeep Singh, Mir Irfan Ul Haq, Ankush Raina, Ankush Anand, Vinay Kumar, Sanjay Mohan Sharma, "Synthesis and tribological investigation of Al-SiC based nano hybrid composite" Alexandria Engineering Journal, 57, 1323 (2018).

47) Sameer Kumar D. , Suman K.N.S., Tara Sasanka C., Ravindra K, Palash Poddar, Venkata Siva S.B., Microstructure, mechanical response and fractography of AZ91E/A12O3 (p) nano composite fabricated by semi solid stir casting method, Journal of Magnesium and Alloys,5,48 (2017).

48) C. Kannan, R. Ramanujam, Comparative study on the mechanical and microstructural characterization of AA 7075 nano and hybrid nano composites produced by stir and squeeze casting, Journal of Advanced Research,8, 309 (2017).

49) Manish Maurya, Nagendra Kumar Maurya, Vivek Bajpai, Effect of SiC Reinforced Particle Parameters in the Development of Aluminium Based Metal Matrix Composite, EVERGREEN Joint Journal of Novel Carbon Resource Sciences \& Green Asia Strategy,06, 200 (2019).

50) Kumar A, Lal S and Kumar S, Fabrication and characterization of A359/A12O3 metal matrix composite using electromagnetic stir casting method. J Mater Res Technol, 2,250(2013).

51) Ezatpour HR, Torabi-Parizi $M$ and Sajjadi SA. Microstructure and mechanical properties of extruded $\mathrm{Al} / \mathrm{Al} 2 \mathrm{O} 3$ composites fabricated by stir-casting process, Trans Nonferrous Met Soc China,23, 1262(2013).

52) Dwivedi S. P, Sharma S and Mishra R. K. Microstructure and mechanical properties of $\mathrm{A} 356 / \mathrm{SiC}$ composites. Proc Mater Sci,6, 1524 (2014).

53) Ezatpour HR, Torabi-Parizi $M$ and Sajjadi SA. Microstructure and mechanical properties of extruded Al/A12O3 composites fabricated by stir-casting process, Trans Nonferrous Met Soc China, 223, 1262 (2013).

54) El-Galy IM, Ahmed MH and Bassiouny BI. Characterization of functionally graded Al-SiCp metal matrix composites manufactured by centrifugal casting, Alexandria Eng J,56, 371(2017).

55) Shahin S, Khoshroshahi RA, Mousavian RT, Stir casting process for manufacture of $\mathrm{Al}-\mathrm{SiC}$ composites. Nonferrous Met Soc China,36,581 (2017).

56) Habibur Rahman $M$ and Mamun Al Rashed HM. Characterization of Silicon carbide reinforced aluminum matrix composite. Proc Eng,90, 103 (2014).

57) Rana RS, Purohit R, Soni VK, et al. Characterization of mechanical properties and microstructure of aluminium alloy-SiC composites. Mater Today: Proc,2, 1149 (2015).

58) Sarada BN, Murthy PLS and Ugrasena G. Hardness and wear characteristics of hybrid aluminium metal matrix composites by stir casting technique. Mater Today: Proc.2, 2878 (2015). 
59) Sulaiman S, Marjom Z, Ismail MIS, et al. Effect of modifier on mechanical properties of aluminium silicon carbide (AlSiC) composites. Proc Eng.184, 773 (2017).

60) Bharath V, Nagaral M, Auradi V, et al. Preparation of 6061 Al-A12O3 MMC's by stir casting and evaluation of mechanical and wear properties. Proc Mater.6, 1658 (2014).

61) Ramesh CS, Keshavamurthy $R$ and Madhusudhan J. Fatigue behavior of Ni-P coated Si3N4 reinforced Al6061 composites. Proc Mater Sci.6, 1444 (2014).

62) Ravi B, Balu Naik B and Udaya Prakash J. Characterization of aluminum matrix composite (AA 6061/B4C) Fabricated by stir casting technique. Mater Today: Proc.2, 2984 (2015).

63) Jebeen Moses J and Joseph Sekhar S. Investigation on the tensile strength and micro hardness of AA6061/TiC composites by stir casting, Trans Indian Inst Met., 70,1035 (2017).

64) Saravana Kumar A, Sasi Kumar P and Sivasankaran S. Synthesis and mechanical behavior of AA6063-X Wt. \% Al2O3-1\% Gr (X1/43, 6, 9 and 12 Wt.\%) hybrid composites. Proc Eng.97,951(2014).

65) Pardeep S, Satpal S and Dinesh K. Production and some properties of Si3N4 reinforced aluminium alloy composites, J Asian Ceramic Soc.,3, 352(2015).

66) Pardeep S, Krishan P, Garg RK, et al. A study on wear behaviour of $\mathrm{Al} / 6101 /$ graphite composites. J Asian Ceramic Soc.5, 42 (2017).

67) Ravikumar K, Kiran K and Sreebalaji VS. Characterization of mechanical properties of aluminium/ tungsten carbide composites. Measurement,102,142(2017).

68) Ch. Kaushik N and Rao RN. Effect of grit size on two body abrasive wear of Al 6082 hybrid composites producedby stir casting method. Tribology Int.102, 52(2016).

69) Vijaya Ramnath, Elanchezhian , Jaivignesh M, et al., Evaluation of mechanical properties of aluminum alloy alumina-boron carbide metal matrix composites. Mater Des. 58, 332 (2014).

70) Nagendra Naik M, Dharma Reddy K, Venkata Ramaiah P, et al. Exploration of mechanical behavior and wear behavior of $\mathrm{A} 4 \mathrm{C} 3$ reinforced aluminum metal matrix composites. Mater Today:Proc.4, 2989(2017).

71) Ilandjezian $R$ and Gopalakannan S. Tensile fracture \& compression failure behavior of cenosphere reinforced AA 6061 MMC. Proc Eng. 173, 1239 (2017).

72) Harini Sosiati, Yankeisna Auda Shofie and Aris Widyo Nugroho, Tensile Properties of Kenaf/E-glass Reinforced Hybrid Polypropylene (PP) Composites with Different Fiber Loading, EVERGREEN Joint Journal of Novel Carbon Resource Sciences \& Green Asia Strategy,5, 1(2018).

73) H.Z. Zhang, H.Y. Wang, F.F. Liu, L. Wang, Investigation on femtosecond laser ablative processing of SiCp/AA2024 Composites, Journal of Manufacturing Processes, 49, 273 (2020).

74) N. Kumar Maurya, M. Maurya, A. Kumar Srivastava et al., Investigation of mechanical properties of $\mathrm{Al} 6061 / \mathrm{SiC}$ composite prepared through stir casting technique,
Materials Today: Proceedings, (2019), https://doi.org/10.1016/j.matpr.2019.09.003

75) S. P. Dwivedi, N. K. Maurya, Manish Maurya. Effect of uncarbonized eggshell weight percentage on mechanical properties of composite material developed by electromagnetic stir casting technique. Revue des Composites et des Matériaux Avancés,29, 101(2019). 